\title{
Parkinsonism in Association with Dihydropteridine Reductase Deficiency
}

\author{
Yoshiaki Takahashi $^{\mathrm{a}}$ Yasuhiro Manabe $^{\mathrm{a}}$ Yumiko Nakano $^{\mathrm{a}}$ \\ Taijun Yunoki $^{a}$ Syoichiro Kono ${ }^{a}$ Hisashi Narai $^{a}$ Mahoko Furujo ${ }^{b}$ \\ Koji $\mathrm{Abe}^{\mathrm{c}}$ \\ a Department of Neurology, National Hospital Organization Okayama Medical Center, \\ Okayama, Japan; ${ }^{b}$ Department of Pediatrics, National Hospital Organization Okayama \\ Medical Center, Okayama, Japan; ' Department of Neurology, Graduate School of \\ Medicine, Dentistry and Pharmaceutical Sciences, Okayama University, Okayama, Japan
}

\section{Keywords}

Dihydropteridine reductase deficiency · Levodopa · Parkinsonism · Hyperphenylalaninemia · SPECT · Dopamine transporter

\section{Abstract}

We report a 16-year-old man with disorders of tetrahydrobiopterin metabolism due to dihydropteridine reductase (DHPR) deficiency. He revealed moderate mental retardation, parkinsonism, and spastic paralysis with levodopa and 5-hydroxytryptophan (5-HTP) supplementation from the age of 2 months. Brain MRI showed high intensity areas in bilateral frontal and posterior deep white matter on fluid-attenuated inversion recovery (FLAIR). Coronal FLAIR image showed a high signal in bilateral pyramidal tracts. Single photon computed tomography (SPECT) imaging of the dopamine transporter was normal. This imaging indicates no dopaminergic cell loss. Our patient had no motor fluctuations or dyskinesias. Early diagnosis and replacement treatment might lead to a favorable outcome. 


\section{Case Reports in Neurology}

\section{Introduction}

Dihydropteridine reductase (DHPR) deficiency is a rare autosomal recessive inherited disease which affects the metabolism of tetrahydrobiopterin $\left(\mathrm{BH}_{4}\right)$, causing hyperphenylalaninemia and neurotransmitter deficiency [1]. Delayed neurological syndromes due to hypomyelination in the central nervous system are recognized and can include parkinsonism [1]. However, the clinical characteristics of parkinsonism and dopamine transporter (DAT) imaging have not been fully documented. Here, we report a case of levodopa-responsive parkinsonism with DHPR deficiency and demonstrate by means of dopamine transporter-single photon emission computed tomography (DAT-SPECT).

\section{Case Report}

A 16-year-old man was admitted to our hospital due to slowly progressive gait disturbance. He was found to have hyperphenylalaninemia on a routine Guthrie test for newborn screening. He was diagnosed as having DHPR deficiency based on a $\mathrm{BH}_{4}$ loading test $[2,3]$. Gene analysis revealed a compound heterozygous mutation of the QDPR gene (G18C/S59X, both are new mutations) [2,3]. At the age of 2 months, treatment was started with $\mathrm{BH}_{4} 15-$ $20 \mathrm{mg} / \mathrm{kg} /$ day, levodopa $15 \mathrm{mg} / \mathrm{kg} /$ day, and 5-hydroxytryptophan (5-HTP) $15 \mathrm{mg} / \mathrm{kg} /$ day. Entacapone $300 \mathrm{mg} /$ day was added at the age of 10. He developed epileptic seizures at the age of 12. To avoid intracerebral folate deficiency, folic acid was added when he was 15 years of age. On admission, the general physical examination was normal. Neurological examinations revealed mental retardation, akinesia, rigidity of upper limbs, hand clumsiness, spastic paralysis, and clonus at the ankles. He had no daily motor fluctuations or dyskinesias. Deep tendon reflexes were hyperactive in all limbs. Babinski, Chaddock, Hoffman, and Trömner signs were positive on both sides. His gait was spastic. There were no obvious abnormalities of the sensory, cerebellar, and autonomic systems. The Mini-Mental State score was $18 / 30$. At this time, the serum phenylalanine (Phe) value was $906 \mathrm{nmol} / \mathrm{mL}$ (normal, 42.6-75.5 nmol/mL). He was taking $\mathrm{BH}_{4} 8.4 \mathrm{~g} /$ day, levodopa $700 \mathrm{mg} /$ day, 5-HTP 800 $\mathrm{mg} /$ day, entacapone $300 \mathrm{mg} /$ day, folinic acid $15 \mathrm{mg} /$ day, and levetiracetam $300 \mathrm{mg} /$ day. Brain magnetic resonance imaging (MRI) showed high intensity areas in frontal and posterior deep white matter on fluid-attenuated inversion recovery (FLAIR) (Fig. 1a) and T2weighted imaging. Coronal FLAIR image showed a high signal in bilateral pyramidal tracts (Fig. 1b). Dopaminergic striatal innervation was evaluated as dopamine reuptake transporter density by means of SPECT and [123I]N- $\omega$-fluoropropyl-2 $\beta$-carbomethoxy-3 $\beta$-(4iodophenyl) tropane (123I-FP-CIT). 123I-FP-CIT SPECT was normal (Fig. 1c). Specific binding ratios were right 7.99 and left 8.13 (normal, >4.00). His spastic gait improved with an antispasmogenic agent.

\section{Discussion}

Our patient revealed normal DAT-SPECT. Levodopa-responsive dystonia is suggestive to our patient. Levodopa-responsive dystonia is due to heterozygote mutations in the GTP cy- 
clohydrolase 1 gene, where an endogenous synthesis of monoamines remains. GTP cyclohydrolase 1, encoded by the GCH1 gene, is an essential enzyme for dopamine production in nigrostriatal cells. Loss-of-function mutations in $\mathrm{GCH} 1$ result in severe reduction of dopamine synthesis in nigrostriatal cells and are the most common cause of dopa-responsive dystonia, a rare disease that classically presents in childhood with generalized dystonia and a dramatic long-lasting response to levodopa [4]. The childhood-onset dystonia subtype has normal DAT imaging; however, DAT imaging was reduced in the adult-onset parkinsonian subtype, indicating Parkinson disease-like nigrostriatal dopaminergic denervation [4]. GCH 1 deficiency and consequent chronic dopamine deficiency with the adult-onset parkinsonian subtype might directly predispose to nigral cell death [4]. Our patient had no signs of monoamine deficiency under long-term replacement therapy despite the severe enzymatic deficiency and the long duration of the disease. This would suggest that a normal level of dopamine exhibits a protective role on the survival of nigral neurons. Findings of parkinsonism in disorders of tetrahydrobiopterin metabolism on DAT imaging have rarely been reported (Table 1). Evans et al. [5] reported a patient who had received a delayed diagnosis of phenylketonuria as an infant and developed motor fluctuations without dyskinesias. Sedel et al. [6] reported a patient who had no daily motor fluctuations or dyskinesias after long-term replacement treatment. Our patient also had no daily motor fluctuations or dyskinesias after long-term replacement treatment. These findings suggest that early diagnosis and treatment with levodopa and 5-HTP might lead to a favorable outcome.

Levodopa-induced motor complications most likely resulted from dopamine neuron loss. Normal DAT imaging implies a good storage capacity of dopaminergic nerve terminals [6]. In addition to our case, 1 adult patient with the use of levodopa from the age of 3 months, despite the severe DHPR deficiency, exhibited no dyskinesia or dopaminergic cell loss, as suggested by normal positron emission tomography (PET) imaging of the dopamine transporter [6]. Although it is still under discussion whether the long-term use of levodopa is toxic for dopaminergic neurons, this observation and our case report suggest that early diagnosis and replacement therapy with levodopa and 5-HTP might have protective effects on brain neurons during development. The accumulation of further clinical cases is needed.

\section{Statement of Ethics}

Informed consent was obtained from the patient for his participation in this case report.

\section{Disclosure Statement}

The authors state that they have no conflicts of interest. They have no financial disclosure to make. 


\section{Case Reports in Neurology}

\section{References}

1 Shintaku H: Disorders of tetrahydrobiopterin metabolism and their treatment. Curr Drug Metab 2002;3:123-131.

-2 Furujo M, Ichiba Y, Sintaku H, Asada M: A case of dihydropteridine reductase deficiency. Pteridines 2000;11:126-128.

-3 Furujo M, Kinoshita M, Ichiba Y, Romstad A, Shintaku H, Kubo T: Clinical characteristics of epileptic seizures in a case of dihydropteridine reductase deficiency. Epilepsy Behav Case Rep 2014;13:37-39.

-4 Mencacci NE, Isaias IU, Reich MM, Ganos C, Plagnol V, Polke JM, et al; International Parkinson's Disease Genomics Consortium and UCL-Exomes Consortium: Parkinson's disease in GTP cyclohydrolase 1 mutation carriers. Brain 2014;137:2480-2492.

-5 Evans AH, Costa DC, Gacinovic S, Katzenschlager R, O’Sullivan JD, Heales S, Lee P, Lees AJ: L-doparesponsive Parkinson's syndrome in association with in vivo dopamine transporter and D2 receptor findings. Mov Disord 2004;19:1232-1236.

-6 Sedel F, Ribeiro MJ, Remv P, Blau N, Saudubray JM, Agid Y: Dihydropteridine reductase deficiency: levodopa's long-term effectiveness without dyskinesia. Neurology 2006;67:2243-2245.

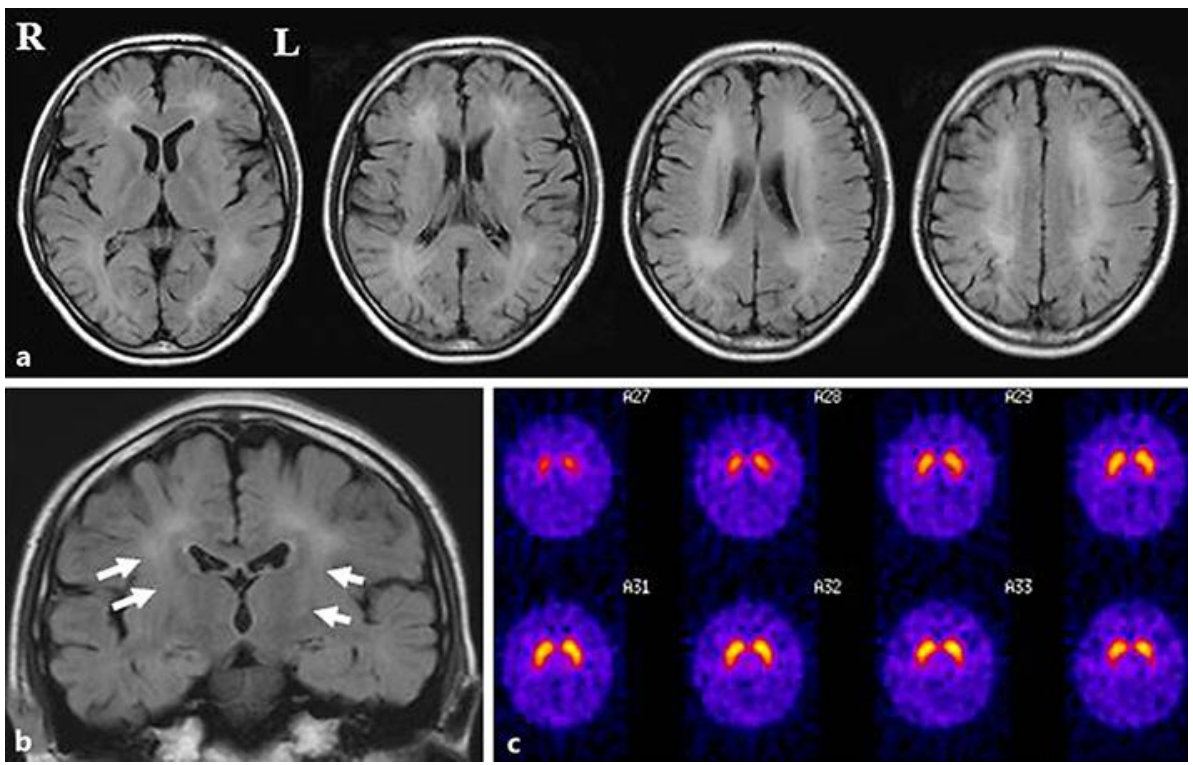

Fig. 1. a FLAIR MRI showing high signal in bilateral frontal and posterior deep white matter. b Coronal FLAIR image showing high signal in bilateral pyramidal tracts (arrows). c [123I]N- $\omega$-fluoropropyl-2 $\beta$ carbomethoxy-3 $\beta$-(4-iodophenyl) tropane single photon computed tomography (123I-FP-CIT SPECT) was normal. 


\section{Case Reports in Neurology}

\begin{tabular}{l|l}
\hline Case Rep Neurol 2017;9:17-21 \\
\hline DOI: $10.1159 / 000456610$ & $\begin{array}{l}\text { C } 2017 \text { The Author(s). Published by S. Karger AG, Basel } \\
\text { www.karger.com/crn }\end{array}$ \\
\hline
\end{tabular}

Takahashi et al.: Parkinsonism in Association with Dihydropteridine Reductase Deficiency

Table 1. Clinical features of patients with disorders of tetrahydrobiopterin metabolism on DAT imaging

\begin{tabular}{|c|c|c|c|c|c|c|c|c|}
\hline Case & $\begin{array}{l}\text { Age/ } \\
\text { sex }\end{array}$ & $\begin{array}{l}\text { Age at diag- } \\
\text { nosis }\end{array}$ & $\begin{array}{l}\text { Age at re- } \\
\text { placement } \\
\text { treatment }\end{array}$ & Symptoms & Deficiency enzyme & $\begin{array}{l}\text { Dopamine } \\
\text { transporter }\end{array}$ & Prognosis & $\begin{array}{l}\text { Authors, year } \\
\text { [Ref.] }\end{array}$ \\
\hline 1 & $37 / F$ & 2 years & 33 years & $\begin{array}{l}\text { gait disturbance, bilateral } \\
\text { postural hand tremor, } \\
\text { hand clumsiness }\end{array}$ & $\begin{array}{l}\text { phenylalanine 4- } \\
\text { hydrolase (PAH) }\end{array}$ & normal & $\begin{array}{l}\text { slowly } \\
\text { progressive }\end{array}$ & $\begin{array}{l}\text { Evans } \\
\text { et al., } 2004 \\
{[5]}\end{array}$ \\
\hline 2 & $29 / \mathrm{M}$ & $\begin{array}{l}\text { newborn } \\
\text { screening }\end{array}$ & 3 months & $\begin{array}{l}\text { akinesia, rest tremor, bilat- } \\
\text { eral ptosis, hypersalivation }\end{array}$ & $\begin{array}{l}\text { dihydropteridine } \\
\text { reductase (DHPR) }\end{array}$ & normal & $\begin{array}{l}\text { slowly } \\
\text { progressive }\end{array}$ & $\begin{array}{l}\text { Sedel } \\
\text { et al., } 2006 \\
{[6]}\end{array}$ \\
\hline 3 & $16 / M$ & $\begin{array}{l}\text { newborn } \\
\text { screening }\end{array}$ & 2 months & $\begin{array}{l}\text { akinesia, rigidity, hand } \\
\text { clumsiness, spastic } \\
\text { paralysis, clonus at ankles }\end{array}$ & $\begin{array}{l}\text { dihydropteridine } \\
\text { reductase (DHPR) }\end{array}$ & normal & $\begin{array}{l}\text { slowly } \\
\text { progressive }\end{array}$ & $\begin{array}{l}\text { Our case, } \\
2016\end{array}$ \\
\hline
\end{tabular}

